\title{
Representation of Colonial Bengali Culture as Depicted in Rabindranath Tagore's Short Stories
}

\author{
Ms. Arundhati Patra
}

SACT (State Aided College Teacher), Department of English, Vivekananda Mission Mahavidyalaya, Vidyasagar University, West Bengal, India

\begin{abstract}
Colonialism especially British Colonialism in India has a great impact on Indian culture especially in Bengal as we know Calcutta is the capital of British India at the colonial period. At the colonial period, undivided Bengal rapidly coloured itself in English, British culture but not every social class rather we find the kind of hybrid culture in so called higher society, economically-culturally rich society. The famous 'Babu' culture is carefully depicted in literature by Rabindranath Tagore. In Tagore's literary writings, we basically find economically-culturally rich society. His most of the male protagonists are from economically rich society and educated that's quite normal in that time. What is abnormal at that time is his representation of female protagonists who are educated at that when society thinks that education is a kind of curse for women because educated women lost their husbands and became widow. In his writings Rabindranath deliberately challenges as well as breaks this social norm and presents a kind of new society where both man and woman are equal, free to choose their own way to lead life. In this paper, I want to show how British culture helps to represent Bengal society newly; how Colonialism influenced Rabindranath to challenge the rotten social norms and to depict a culturally modern Bengal; the importance of myth to reshape Bengali culture in his writings. As a case study, I select few of Rabindranath Tagore's short stories (translated version).
\end{abstract}

Keywords-Babu Culture, Bengal society, Myth, Representation of Women.

Colonialism especially British Colonialism in India has a great impact on Indian culture especially in Bengal as we know Calcutta is the capital of British India in the colonial period. Rabindranath Tagore, one of the leading figures of the great Bengal movement called The Bengal Renaissance, takes a difficult step to depict Bengali culture newly; or rather it's better to say Modern Bengali culture. He deliberately breaks the rotten social norms through his modern thinking that's presented in a form of the literary piece. Rabi Thakur depicts Bengal society in two wayswhile in most of his novels he presents economically rich Bengal Society, in most of his short stories he depicts comparatively economically backward Bengal society. This is the basic difference between his novels and short stories. But we find an important similarity both of his novels and short stories is the issue of modernity basically the way his protagonists are depicted with modern thinking and broadminded. In most of his novels and short stories, Rabi Thakur depicted women characters very carefully, presents them educated, modern at that time when society thinks that education is a kind of curse for women because educated women lost their husbands and became widow. In his writings, Rabindranath deliberately challenges as well as breaks this social norm and presents a kind of new society where both men and women are equal, free to choose their own way to lead life. In my paper, I am dealing with some of his short stories as a case study. These are- The ExerciseBook, The Golden Deer, Grandfather, Woman Unknownall are translated versions.

In the colonial period, the undivided Bengal society rapidly coloured itself in English that is British culture but not fully rather hybrid culture. At that time, Bengal is famous for socalled Babu Culture. These so-called Babus create a kind of colonialism in the undivided Bengal as the Britishers did. But Rabi Thakur depicts this so called Babu Culture in his short story Grandfather quite differently. In Grandfather Tagore presents the Babus of Nayanjore sarcastically. The title 'Babu' is just like the title 'Raja' or 'Rai Bahadur' to the 
common people. The Babus of Nayanjore, as Rabindranath depicted, "wore dhotis of Dhaka muslin after tearing off the edges, because the stiffness of the borders hurt their sensitive babu skins. They spent a hundred thousand rupees to celebrate their kittens' weddings. It was rumoured that once during some festival, vowing to turn night into day, they lit innumerable bright lamps and by that light, simulated sunbeams by showering pure silver thread from above" (SSS- GRANDFATHER: PP-126). In Grandfather, Rabi Thakur depicts a kind of difference between "the declining feudal order and the new capitalism" based on socio-economic system. Kailaschandra Ray Choudhuri, "an extinguished lamp of the famous babu family of Nayanjore" (SSS- GRANDFATHER: PP126), represents "the declining feudal order" and the unnamed young eligible bachelor basically the narrator, neighbor in Calcutta, represents "the new capitalism". Although the declining feudal pride is hollow it is harmless than the uncompromising, malicious new capitalism that is comparatively harmful for human beings. We see at the first of the story the narrator doesn't like Kailaschandra due to his false pride as well as Kailas babu's family reputation that "the Babus of Nayanjore never approached anyone with any prayer" (SSS- GRANDFATHER: 130). The narrator's hostility to Kailas Babu is clearly penned as Rabi Thakur wrote: "I have already mentioned that Kailas Babu had a granddaughter. I had seen her many times but did not think she was beautiful; hence the idea of marrying her never crossed my mind. Nonetheless I had expected that Kailas Babu, either in person or through emissaries, would initiate the ritual of worship with his granddaughter as offering, seeing that $I$ was such a fine young man. But he did no such thing" (SSSGRANDFATHER: 130). The neighbours called Kailas Babu as "Grandfather". Though they know the exact present economic condition of Kailas Babu, they never put him down rather they treats him affectionately except the narrator who planned to hurt his feudal pride by presenting his friend as an Englishman better to say the Lieutenant- Governor who will come to see Kailas Babu in his house. What is important in this story is not only to present Babu Culture sarcastically but also to present modernity through his female character. Kusum, Kailas Babu's granddaughter, is a main key to bridge the two different systems: "the declining feudal order and the new capitalism". One of the important issues of modernity is the representation of women. Here Rabi Thakur depicts Kusum as a source of giving light in the darkness as the narrator said: "suddenly now, I realized how brutally I had assailed a sensitive spot. Suddenly, the ugly cruelty of my deed blazed before my eyes. I slunk out of the room in shame and remorse, like a dog that has been kicked. Indeed what damage had the old man done me? His harmless pride never hurt anyone. Why then did my pride take on such fierce shape?" (SSSGRANDFATHER: 132).

Rabindranath Tagore wants to give the women the power to establish their own identity in his writings. He raised his voice against Hindu revivalism, religious and social orthodoxy. At that time it's quite normal that a man can make himself educated but what is abnormal is that a woman has not any right better to say that the society doesn't give any right to make herself educated because according to Hindu believes education is a kind of curse for women because educated women lost their husbands and became widows. But Rabindranath deliberately breaks this social rotten norm and to take this challenge, who helped him is British Colonialism. Here'sthe importance of British Colonialism to reshape the Bengal mind as well as Bengal society. In the short story The Exercise-Book, translated by Supriya Chaudhuri, Rabi Thakur raises his voice against Hindu believes. Uma, the protagonist of this story, wrote a notebook, loves to read and write. But unfortunately, she failed to continue her passion at the end by the hands of patriarchal society. This so- called educated patriarchal society destroys her dream. At the age of nine, Uma got married and went to in-law's house by taking her note book. The story centers on three note books, belonging to Uma, her elder brother Gobindalal and her husband as well as her brother's friend Pyarimohan. But there is a difference between these three books: Gobindalal and Pyarimohan's notebooks represent "revivalist Hindu rhetoric" while Uma's notebook represents nothing but her own heart, her dream, and her belongings. Uma, the alternative name of Devi Durga who was made of by Devs like Brahma, Vishnu, and Shiva and killed Asuras, failed to kill the social rotten Hindu believes that education was considered as a prelude to widowhood that was the thought of her educated husband Pyarimohan. To Pyarimohan, "If women began to read and write, novels and plays would soon make their way into the home and it would be hard to uphold the household virtues.....he said that, the power of the female and the power of the male together produced the sacred power of the conjugal relationship; but if the power of the female was vanquished through education and study, the power of the male alone would be paramount. Then male power 
would clash with male power to produce so terrible a destructive energy that the power of the conjugal bond would be completely destroyed, and so the woman would become a widow" (SS-THE EXERCISE BOOK: 48). Actually, through the character of Pyarimohan, Rabi Thakur presents the common men society or better to say patriarchal society. Here's the difference between Goddess Durga and a simple housewife Uma. By using the name of Uma, Rabindranath Tagore highlights the different attitude of society towards women: at the one hand, the society worships the female power as the name of Goddess Uma; on the other hand, that society snatches the basic rights of the female as the name of common housewife Uma.

Myth has its own importance in literature. Writers take mythological events as the source materials of their writings. Rabindranath Thakur also takes the mythological event for his short story, The Golden Deer (translated by Madhuchuchhanda Karlekar), differently. For The Golden Deer, he just takes the essence of the plot from the episode of The Ramayana where Sita demanded to give her golden deer to Lakshmana and that golden deer was sent by the Rakshasa Ravana and for that, the war of Ramayana started between Ram and Ravana. But in this story, Rabindranath transforms "this Raksha-made illusion into one devised by the Yaksha- the illusion of wealth" (SS-INTRODUCTION15). The illusion of wealth separated Baidyanath from Mokshada who sent Baidyanath, her husband to Varanasi where "a certain house contained hidden treasure, or so it was popularly believed" (SS- The Golden Deer-91). For Baidyanath, Varanasi, the holy city to die, seems like "his impending death" (SS- The Golden Deer-91). The illusion of wealth leads Baidyanath to a hollow world where he found nothing but an empty treasure-jars and old bones: "He gave up at last with a great sigh of despair. His heartrending ' $O$ Mother!'....the cries of many such wretches from the past" (SS- The Golden Deer-91). The golden deer that represents the illusion of wealth spoils his simple, unambitious joy of life. Here Rabi Thakur shows the real modern sordid life through the images of the old myth of The Ramayana.

In the journal of Sabujpatra (The Green Leaf), Tagore basically paints the elite class society. The short story Aparichita (Woman Unknown, translated by Meenakshi Mukherjee) was published in this journal. The story basically centers on an unknown woman named Kalyani who is unknown to Anupam who loves her in his world of imagination and eventually encounters her on a train but that point he didn't know who she is. Rabi Thakur deliberately challenges the social customs through the character of Shambhunath Sen, Kalyani's father, who breaks his own daughter's marriage just for protecting her respect: "I cannot give my daughter in marriage to a family that considers me capable of stealing her gold" (SS-WOMAN UNKNOWN-224). Even Rabi Thakur shows an unusual reversal of custom that Kalyani can get an opportunity to work out Anupam's photograph during the wedding negotiations but Anupam doesn't get an opportunity to see her photograph. These events show Tagore's modern thought at that time when society was surrounded by social rotten dogma. Even at the end of the story, we find both Anupam and Kalyani as unmarried youth. It's quite normal that a person can do anything what he wants in that so-called patriarchal society. But what's abnormal is that therein socalled patriarchal society, Kalyani, being a woman, refused to urge married and leads her life own way as she wishes; " I am not going to marry...After the fiasco of her marriage, she had dedicated herself to the education of girls" (SSWOMAN UNKNOWN-230). Both the characters of Shambhunath and Kalyani, as depicted within the story, highlight how the British culture influenced on colonial Bengal society, the elite up growing society.

\section{CONCLUSION}

To conclude, I would like to mention that Rabi Thakur is that casual effect that bridges the East- West thought. Within the colonial Period, he deliberately challenges the social Bengali orthodox. Tagore's heroines are openly challenging social evils as widow-remarriage, the rigid caste-system and patriarchy at large. In his writings Rabi Thakur presents the women characters as mystic figures as well as educated, as he said: " narir hridoyer ontor rohoshoy ved oti sohojotam bisoy noy" (it's hard to understand the mysticism of woman character).

\section{REFERENCES}

[1] Sukanta Chaudhuri. Selected Short Stories: Rabindranath Tagore: Oxford University Press. India.2000

[2] Pramod K.Nayar. Literary Contexts: Postcolonial Literatures: Orient BlackSwan. 2016

[3] Elleke Boehmer: Colonial \& Postcolonial Literature: Oxford University Press. New York. 2005

[4] Cohen, Percy S, . "Theories of Myth": Man, Sep., 1969, New Series, Vol. 4, No. 3 (Sep., 1969), pp. 337-353: Royal 
International Journal of English Literature and Social Sciences, 5(4)

Jul-Aug 2020 /Available online: https://ijels.com/

Anthropological Institute of Great Britain and Ireland: http://www.jstor.com/stable/ 2798111

[5] Hendy, Andrew Von: The Modern Construction of Myth: "Rethinking Contemporary Mythologies": Volume-1, Article2: Disclosure: A Journal of Social Theory:

DOI- https://doi.org/10.13023/DISCLOSURE.01.02. 